\title{
Mesa 3
}

\section{Visiones ideales del consumo}

\author{
Raúl EGUIZÁBAL ${ }^{1}$ \\ Universidad Complutense de Madrid
}

\begin{abstract}
RESUMEN:
La razón de ser primordial de la publicidad en la sociedad es incentivar el consumo de las mercancías, sobre todo de las producidas en masa, por lo que está básicamente vinculada a la fabricación en serie y a la reiteración. El arte, sin embargo, pretende lograr una obra única, original e irrepetible. A lo largo de los años, sin embargo, se han producido numerosos contactos e interacciones entre publicidad y arte. No obstante, vamos a estudiar esos vínculos mediante la incursión en el consumo, su nacimiento en los tiempos modernos, el consumo de elite y el consumo de masas y su trayectoria en la llamada sociedad de la información.
\end{abstract}

PALABRAS CLAVE: publicidad, arte, consumo, consumo de elite, consumo de masas.

TITLE: Visions consumption ideals

\begin{abstract}
:
The main raison d'être of advertising in society is to encourage the consumption of goods, especially of mass produced, so it is basically linked to the mass production and repetition. The art, however, aims to achieve a unique work original and unique. Over the years, however, there have been many contacts and interactions between advertising and art. Nevertheless, we will study those links by the raid on consumption, its birth in modern times, the use of elite and mass consumption, and its path in the call information society.
\end{abstract}

KEY WORDS: advertising, art, consumption, elite use, mass consumption

La obligación original e inmediata de la publicidad, aunque con el paso de los años haya adquirido otros compromisos y derivas, ha sido la de incentivar el consumo de las mercancías, y fundamentalmente la de aquellas mercancías producidas en masa a partir de la llamada Revolución Industrial. La publicidad está por tanto vinculada a la fabricación en serie, a la repetición y, por consiguiente a la monotonía; sus propios mensajes tienden a la reiteración, sus recursos retóricos hacen

1 Catedrático de Comunicación Audiovisual y Publicidad, Facultad de Ciencias de la Información. Correo electrónico: r.eguizabal@ccinf.ucm.es 
referencia a un repertorio limitado que se reproduce una y otra vez. Por el contrario, el arte se presenta siempre con la ambición o con el espíritu de constituirse en obra única, original e irrepetible. Y, sin embargo, basta una mirada a las imágenes producidas a lo largo del siglo pasado para percibir los plurales contactos, coincidencias y contaminaciones que se han multiplicado entre dos discursos que aparentemente deberían haberse movido espalda contra espalda. Para estudiar, aunque sea de una forma somera, estos vínculos vamos a seguir no el discurrir del arte o la publicidad, sino el del consumo eligiendo, para ello, momentos bien definidos del mismo relativos al nacimiento del consumo moderno, al salto del consumo de elite al consumo de masas, y a la deriva del consumo en la denominada sociedad de la información.

El hecho es que, con el paso de los años, el concepto de arte se ha ido volviendo más y más inasible; sus fronteras se han tornado tan difusas que intentar poner de manifiesto los vínculos de lo que, más o menos convencionalmente, consideramos arte con otras formas de expresión-comunicación, léase publicidad, puede resultar un ejercicio fútil o comprometido puesto que apenas podemos apreciar contornos definidos entre uno y otro, ni siquiera por el lado de su mercantilización. Estamos hoy, a comienzos del siglo XXI, menos seguros de lo que es o no arte que hace cien años. Incluso la palabra «arte» ha terminado convirtiéndose en algo incómodo que algunos críticos y teóricos procuran evitar.

Algo más de certeza poseemos a la hora de definir la publicidad gracias a su empleo de soportes bien definidos, de códigos establecidos y compartidos desde hace tiempo y a sus restricciones legales que le obligan a colgarse la etiqueta de «publicidad» a la menor sombra de duda. Pero en la medida en que esta, desde hace algunas décadas, forma parte del entorno expositivo establecido (recordemos, para no aburrir con ejemplos que no añaden demasiado al tema, un par de casos: la muestra Art \& Pub en el Pompidou y la de High \& Low en el MOMA, ambas en 1991), parece manifestarse una voluntad de jugar a la confusión de un gusto muy, por decirlo de alguna manera, «postmoderno». Ya saben: fusión, eclecticismo, mestizaje, el fin de las barreras, y el «todo vale» como principio rector. Por si esto fuera poco, en los primeros años del milenio -consecuencia del desconcierto reinante entre el sector, culpa de la llegada de un nuevo medio de imponentes opciones pero todavía en una fase experimental, y de la pérdida de lugar del tradicional creativo publicitario- nos hemos encontrado con una proliferación de acciones publicitarias de diferentes clases más cercanas al happening, la performance o el arte en la calle (Fig. 1), que a las formas convencionales de la comunicación publicitaria. En realidad, de un tiempo a esta parte, empezamos así mismo a no saber qué es exactamente la publicidad. 
Fig. 1 Performance o el arte en la calle

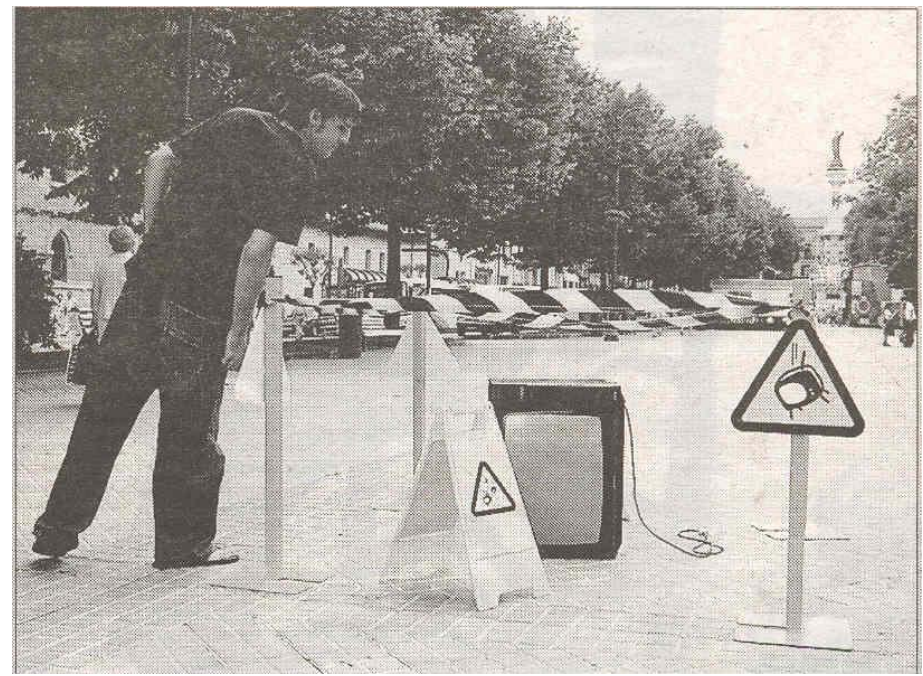

Si la publicidad posee la obligación de colgarse el letrero de «publicidad» cuando juega a la intertextualidad o a la simple confusión de géneros, apenas podríamos concebir, en apariencia, un arte que llevase colgado del cuello, a manera de sambenito, la palabra «arte». Y sin embargo nunca ha necesitado, más que hoy, el arte la concurrencia de marcas extratextuales (bien en forma de textos aclaratorios o bajo la especie de contextos o escenarios) que manifiesten su condición artística o sea, en definitiva, su «valor», y su necesidad de ser reconocido como arte. Nunca ha sido el arte más esclavo de la palabra, hasta el punto en que la obra tiende a confundirse con su discurso.

Para no demorar más este pequeño estudio de concurrencias y para, evitar, al mismo tiempo repetir lo que otros (y yo mismo) han dicho y contado, voy a referirme brevemente a algunas obras artísticas que manifiestan, sin tapujos, su dependencia, más orgánica que temática, de la publicidad. Cada grupo de ellas queda enmarcado en un diferente escenario de consumo, desde la segunda mitad del siglo XIX hasta nuestros tiempos, manifestando así que esos vínculos no son recientes ni se limitan a una forma o movimiento artístico.

\section{Palabras en sumisión}

A mediados del siglo XIX, se dibujó un nuevo escenario del consumo, consecuencia de aquellos cambios, en los órdenes social y cultural, que se estaban produciendo en esas fechas. El mismo proceso de modernización que se había origina- 
do en el entorno de la producción se promovió en el del consumo. Los grandes almacenes, con su capacidad para armonizar mercancías heterogéneas y evitar así las consecuencias de la estacionalidad, la venta por catálogo y la publicidad en periódicos y carteles contribuyeron decisivamente a la constitución de ese nuevo espacio del consumo.

Pocos documentos tan fieles como la novela de Zola Au bonheur de dames para conocer en detalle los profundos cambios en los escenarios de consumo. Todas las técnicas de promoción y comercialización se encuentran ahí reflejadas con la precisión de un genuino científico social. No en vano, Zola creía en las posibilidades de una «novela científica», basada en la observación y la experimentación. Y a la redacción de la obra (que se publicó en forma de folletón entre 1882 y 1883) le antecedió una minuciosa recopilación de datos que duró varios años y de la que se conserva amplia documentación.

Gracias a la obra de Zola, conocemos, por ejemplo, que antes de la puesta en venta de las novedades de verano, los centros comerciales de la época realizaban un lanzamiento de catálogos, y que su número alcanzaba la todavía hoy escalofriante cifra de doscientos mil, de los cuales cincuenta mil eran destinados al extranjero, debidamente traducidos a diferentes lenguas, y que se gastaban del orden de doscientos mil francos, de los de entonces, en anuncios, carteles y publicidad de todo orden; y se desmenuzaban más de cien mil francos en tejidos para hacer muestrarios.

Los casos estudiados por Balzac fueron básicamente dos, Au bon marché, el pionero de los Grandes Almacenes (y que, por cierto, Picasso utilizó en una obra de 1913), y el llamado Louvre, fundado en 1885. Gracias a la literatura interesada por la publicidad, observamos estrategias como la presentación del género con un nuevo sentido tanto de lo espectacular como de lo estético. Zola describe la «instalación» del género blanco, toda una sección que se convertía en protagonista; el resultado era una orgía de blanco, de sábanas, de servilletas y pañuelos, tejidos e indianas, armiños, decoraciones con botones de nácar, arquitecturas de calcetines blancos, toda una sala recubierta de muletón blanco, borbotones de muselina blanca, escaleras recubiertas de tejidos blancos de piqué y bombasí, etc. Todos los blancos y nunca el mismo blanco. Pero lo mismo podía dedicarse a Japón, que entonces empezaba a estar muy de moda en Europa, o al Extremo Oriente, y en aquel momento podían verse así las estanterías desbordadas de viejos marfiles, bronces y lacas, sedas y papeles. Un salón oriental aparecía compuesto únicamente con alfombras de Ispahán, Teherán, Madrás; cortinajes de Karamanie, de Siria; amueblada con sillones y divanes como la tienda de un bajá suntuoso. Todo un delirio de consumo para colmar las aspiraciones de estilo de la nueva clase burguesa.

Quizá lo más extraordinario de todo este despliegue de artimañas no era el mero aumento de las ventas, no la simple expansión del comercio, sino la creación de una auténtica cultura del consumo, de un nuevo ritual, de nuevas costumbres y de 
nuevos significados. Así como la expansión de las maneras burguesas por el contacto de los trabajadores con la clientela adinerada: las vendedoras adoptaban la forma de vestir y hablar de las damas, las criadas imitaban a sus señoras, se cubrían de un barniz cultural construido con lecturas de algunos periódicos, capítulos de algún novelón, frases hechas y opiniones establecidas. Mostraban sus aspiraciones de ascenso social comprando jabones de lujo o lencería fina para acabar pareciendo parte de una clase social nueva e imprecisa entre la trabajadora y la burguesa.

Si Zola, y antes Balzac en obras como Grandeza y caída de César Birotteau (1837) daban cuenta de las transformaciones sociales de su tiempo, Mallarmé, unos años después, fue más allá al captar la tensión poética de los anuncios, deslumbrado no por las hazañas del nuevo comercio sino por las extravagancias de los pequeños mensajes que empezaban a poblar los periódicos.

Hasta entonces la publicidad había sido poco utilizada, no solo por los minoristas, también por los fabricantes. Las tarjetas de comerciante que se utilizaban en Inglaterra desde el siglo XVIII era una de las formas más precoz de publicidad (y una inspiración para el músico Erik Satie en sus billetes caligrafiados) (Fig. 2).

Fig. 2 Billetes caligrafiados

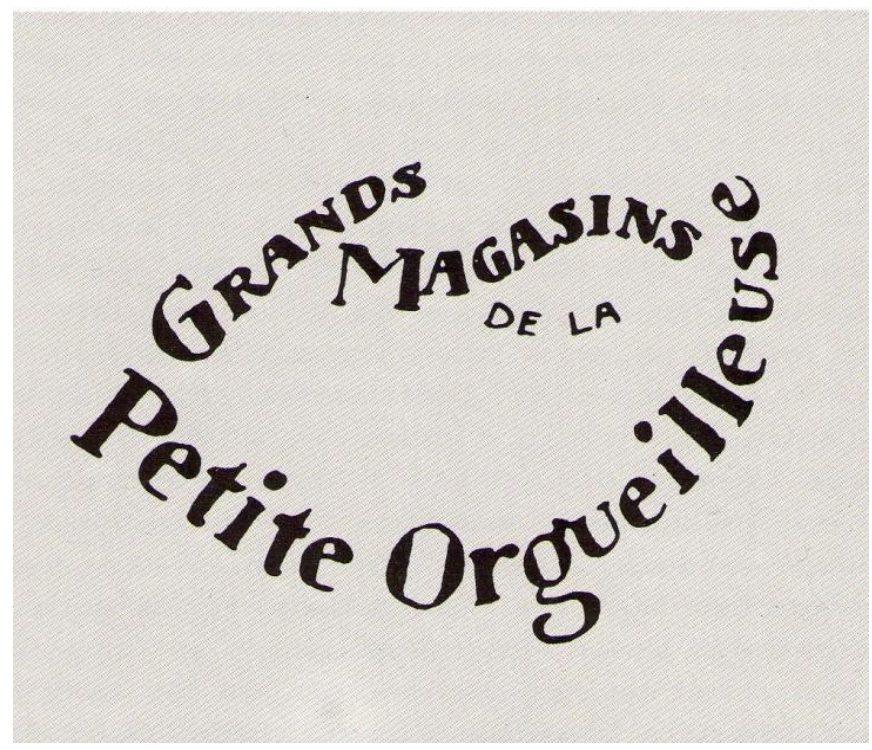


El empleo de los periódicos y revistas tampoco era habitual, pues consideraban la publicidad una actividad poco seria más propia de charlatanes, de fabricantes de medicamentos patentados o pócimas milagrosas. Los anuncios que aparecían en algunas publicaciones eran de tipo redaccional, a veces innecesariamente prolijos y poco llamativos, como los que recoge Balzac en la obra antes citada. Seguramente fue Walter Benjamin quien, en primera instancia, destacó la deuda de la poesía de Mallarmé con las tensiones gráficas de la publicidad: «Mallarmé que desde la cristalina concepción de su obra, sin duda tradicionalista, vio la verdadera imagen de lo que se avecinaba, utilizó por vez primera en el Coup de dés las tensiones gráficas de la publicidad, aplicándolas a la disposición tipográfica» ${ }^{2}$. Si Mallarmé abrió el camino, los posteriores experimentos futuristas y cubistas, caligramas y poemas visuales, utilizaron las formas tipográficas publicitarias avant la lettre. Para evitar la monotonía de los anuncios de los periódicos, limitados al empleo del texto, los publicitarios recurrían a las elasticidades de la escritura manejando diversos tipos y tamaños de letra, repitiendo una misma línea de texto ocho o diez veces, jugando con el espacio en blanco para formar figuras a partir de los caracteres tipográficos (Fig. 3), torciendo las líneas de texto (Fig. 4), pues en muchos soportes estaba restringido el empleo de ilustraciones para los mensajes comerciales. Fueron entonces las restricciones de los editores de periódicos y revistas quienes obligaron a buscar soluciones creativas y llamativas sin más recurso del que valerse que el tipográfico. No eran divertimentos ni experimentos estéticos, eran anuncios, textos con una función específica: incitar al consumo de mercancías y servicios. Pero, sin saberlo, abrieron una caja de Pandora que dio lugar a todo tipo de exceso vanguardista en el que la letra no tenía ya más valor que la mancha.

2 W. Benjamin (1955): Dirección única, Madrid, Alfaguara, 1987, 37. 
Figs. 3 y 4. Elasticidades de la escritura
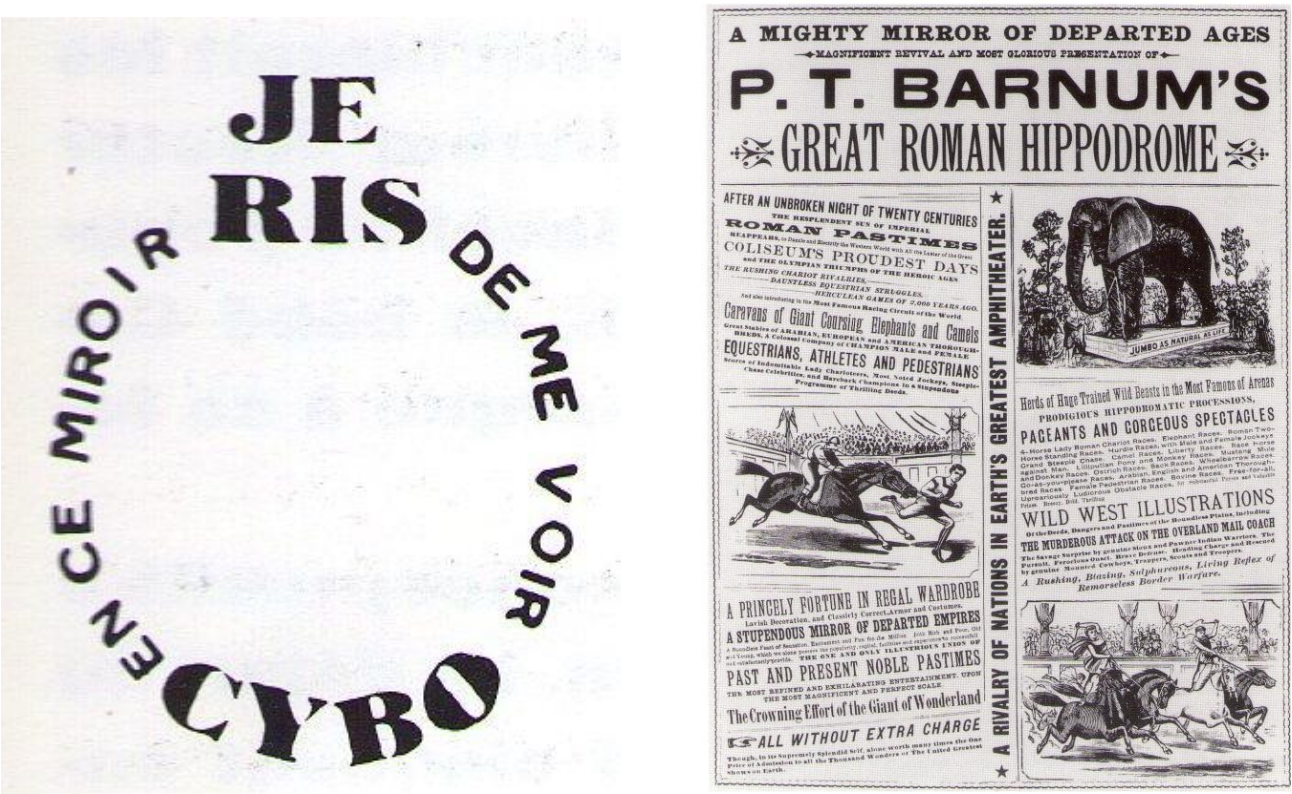

Esas audacias no pasaron desapercibidas, en los años siguientes, a los futuristas y cubistas, tan atentos a las manifestaciones de la vida moderna, a los descubrimientos de las nuevas formas de comunicación, a las gracias de las artes industriales, del vapor y la electricidad. Medicinas, establecimientos comerciales, ungüentos, venta y alquileres de terrenos, cosméticos, espectáculos, moda, cafés y restaurantes, limpiadores, licores y tabaco se envolvían para entonces en toda suerte de bizarrías tipográficas.

Si el primero que se dejó seducir por estas insolencias de la página impresa, al menos al entender de Benjamin, fue Mallarmé, el siglo XX muestra un amplísimo recorrido de experimentos a medio camino entre lo literario, lo propagandístico, lo gráfico y lo tipográfico que incluye a Marinetti, Apollinaire (véanse las Figs. 5 y 6), El Lissitzki, Wyndham Lewis, Luico Venna, Raoul Hausmann, Fernand Leger, H. N. Werkman, Theo Van Doesburg, y muchos otros. Y que en ciertos casos muestra al desnudo su deuda publicitaria: Tzara, Depero, Paul Morand (Fig. 7), Kurt Schwitters. 
Figs. 5, 6 y 7. Marinetti, Paul Morand y Apollinaire

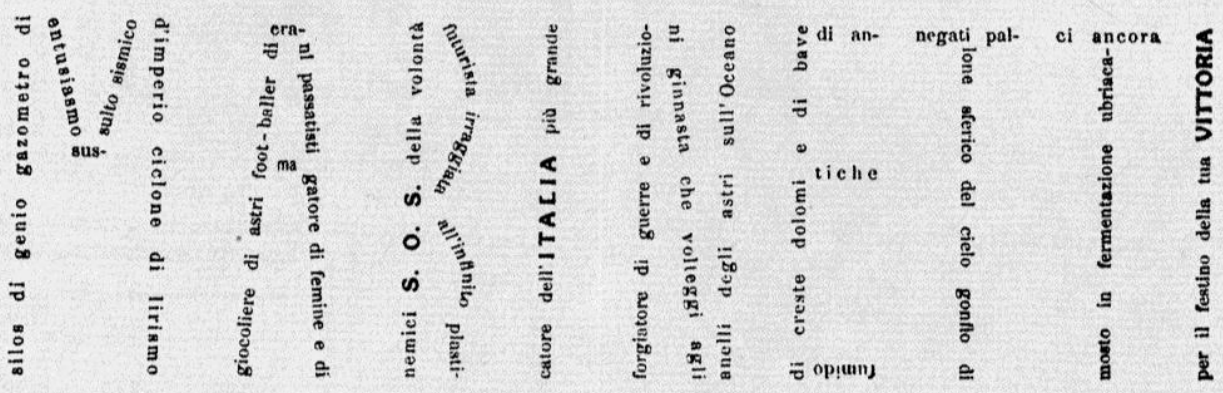
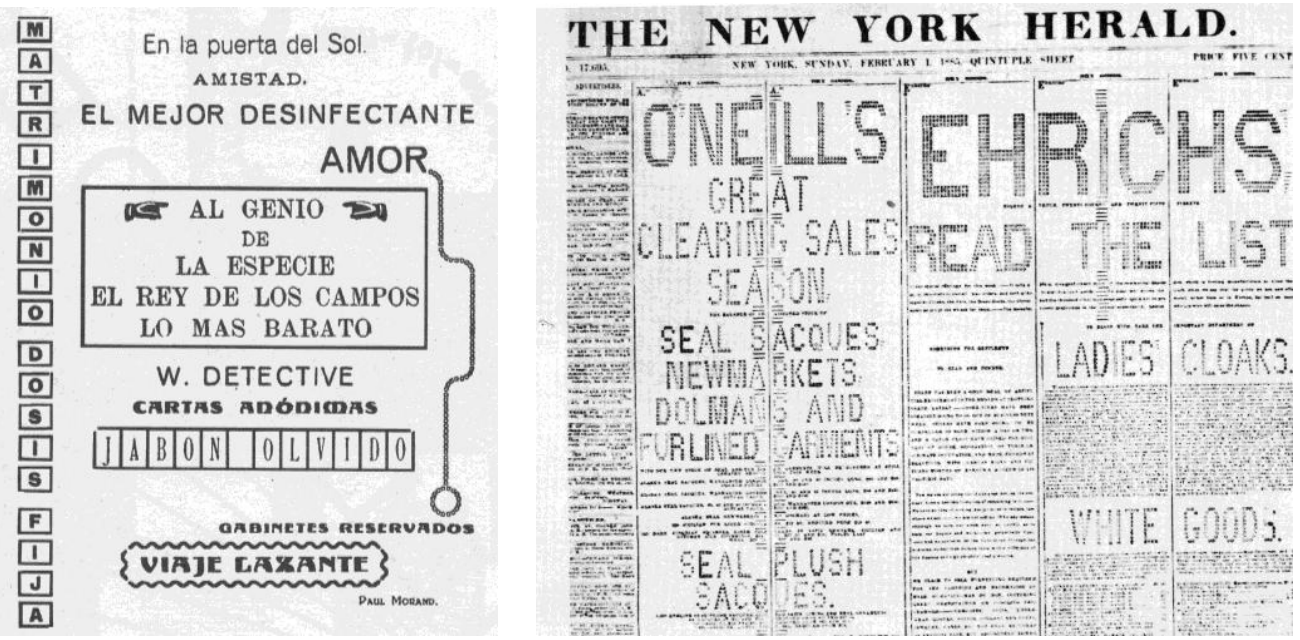

Algunos de ellos (Depero, el Lisstizky, Maiakovsky y Rodchenko, Stepanova, Klucis) se dedicaron de pleno a la publicidad o a la propaganda, demostrando que la comunicación comercial (y la política) era un camino tan válido como cualquier otro, y más abierto a los nuevos tiempos, para seguir siendo artista, para ser un artista de su tiempo. Los eslóganes de Maiakovsky aleteaban en los oídos de los ciudadanos en la Rusia de los años veinte como «pequeños poemas vibrantes». Las frases se cortaban según su ritmo oral, su significado, su entonación, y a cada una de estas partes se le proporcionaban características propias de tipo, cuerpo y color, según fuese su función en el mensaje. Rodchenko se encargaba de las imágenes y entrambos empleaban una sintaxis organizada, enérgica y agitadora. 


\section{Exuberancia de formas y signos}

Nuestra segunda parada, en el trayecto del consumo, son los años cincuenta, la época en la que se constituye, al menos en los EE.UU., la llamada «sociedad de consumo».

Si el escenario social que había surgido de la Revolución Industrial estaba abocado a la producción, el que surgió tras la Segunda Guerra, y después de los años de la Gran Depresión, estaría fundamentado en el consumo como motor de la economía, y de lo social tanto como de lo cultural. No es casual que la década siguiente constituyese la edad dorada de la publicidad, los años de la Revolución Creativa, del optimismo pop y del desenfreno psicodélico, de la promoción de las capas juveniles al poder adquisitivo (y al poder a secas), los años del consumo a 45 revoluciones por minuto. Y todo ello aparecía, en los postreros años cincuenta americanos, pintado en tonos varios de rosa: frigoríficos de enormes dimensiones, rock and roll, pasteles de fresa, motocicletas, tabaco Marlboro, pelos cardados, macedonias de fruta, pantalones vaqueros, gaseosas de colores, Doris Day, sofás de skay. En fin, todas esas cosas que hacían soñar a las amas de casa españolas todavía sumergidas en los años del sucedáneo, el Biscúter y la alpargata. Si América era para entonces, y al decir de Henry Miller, la «pesadilla de aire acondicionado», España era todavía la «pesadilla del botijo».

Como década de prosperidad en los Estados Unidos, y recién escapados de la dieta forzosa de la guerra, los cincuenta mostraron una tendencia enfermiza hacia la exuberancia en los diseños, en los mensajes y en los cuerpos de la estrellas de cine. Los parachoques cromados de los grandes automóviles rivalizaban con el busto prominente y aerodinámico de Jean Russell o de Marilyn Monroe; no en vano los sujetadores los diseñaban los mismos cerebros que los aeroplanos.

Aunque los artistas más vinculados al consumo sean, por supuesto, Warhol y Wasselmann (sin olvidar a Claes Oldenburg con sus hamburguesas gigantes y sus cucuruchos de helado ciclópeos) (Fig. 8), vamos a detenernos, por un instante, en la obra pionera del británico Richard Hamilton, ¿Qué hace que los hogares de hoy sean tan distintos, tan seductores?, pues en ella se recogen de una manera anticipada (estamos hablando de 1956 todavía en los inicios de la «res» consumista) todos los estigmas de la época venidera: gadgets eléctricos, vulgaridad, culto al cuerpo, acumulación, iconos mediáticos, exceso, trivialidad, erotismo. 
Fig. 8. Cucurucho de helado ciclópeo

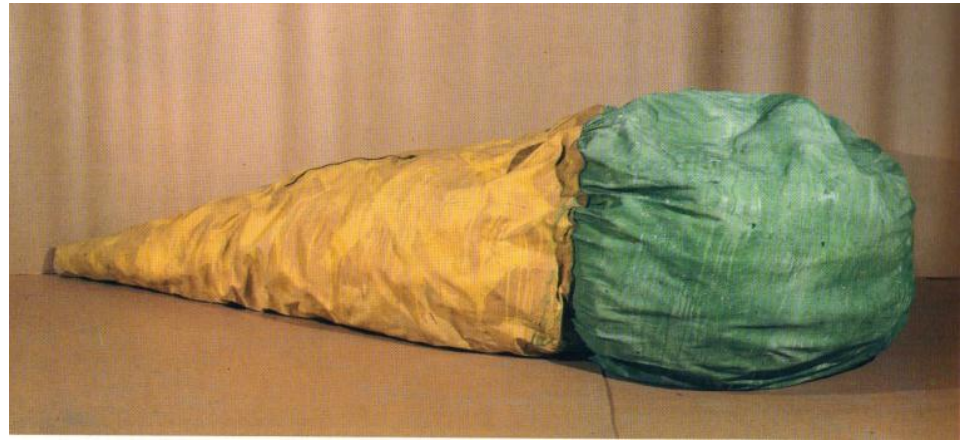

El propio Hamilton definió el pop como «popular, pasajero, perecedero, barato, producido en serie, joven, ingenioso, erótico, artero, encantador y un negocio a gran escala». Hamilton trabajó de joven en el departamento de publicidad de una empresa eléctrica, también lo hicieron Warhol, Rosenquist y otros como el cinético Vasarely. Sus vínculos con la publicidad fueron a un tiempo orgánicos y temáticos (véanse las Figs. 9 y 10), no se conformaron con citar envases y apropiarse de marcas, quisieron llevar al arte, a lo que quedaba de él por entonces, el espíritu de la publicidad: esa secreción massmediática, ese residuo de nuestro tiempo, popular, seductor, producido en serie, a veces ingenioso, siempre joven y encantador, $y$, por supuesto, un negocio a gran escala.

Figs. 9 y 10. Pop Art

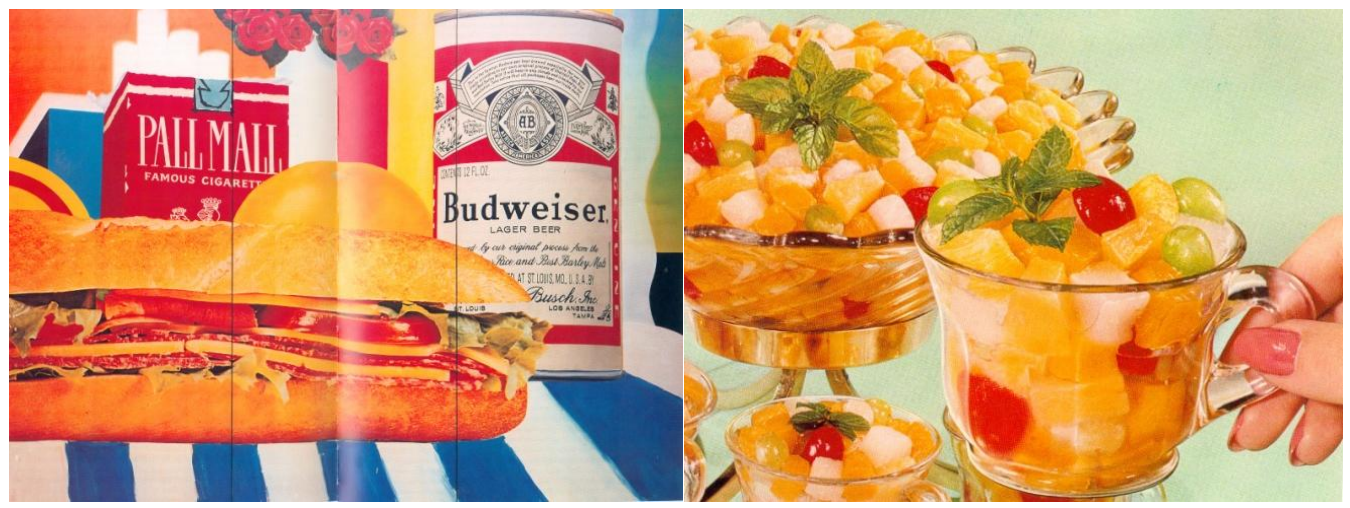

Son los años de la abundancia, del exceso de proteínas, del exceso de color, del exceso de signos. Los carritos del supermercado debían rebosar, las copas de 
cerveza se muestran en los anuncios desbordantes de espuma, los frigoríficos colmados de viandas, las mesas cargadas, los automóviles excesivos en su tamaño y en su contundencia aerodinámica, los escotes generosos. América era una mezcla de hamburguesa gigante, con sus ingredientes sobresaliendo entre las lonchas de pan, y de Raquel Welch, con sus senos y muslos sobresaliendo del bañador de piel de mamut. Es la era de la exuberancia, del derroche, en la que la figura más recurrente es la redundancia, una figura tan querida por la publicidad, sobre la que ejerce algo así como un monopolio contaminador. Las imágenes de Warhol -botes de sopa, pistolas, retratos de Mao o de Marilyn, sillas eléctricas-con su repetición incesante terminan creando un efecto perturbador o una pérdida de sentido, el mismo que el anuncio que se repite en la pantalla una y otra vez, una y otra vez, una y otra vez.

Pero la publicidad no solo tiende puentes con la gráfica o la plástica, también la música recibió sus dosis de virus publicitario, cual alienígena instalado en las entrañas sonoras de la América de los sesenta. Robert Fink, en un estudio sobre la música minimalista, señalaba que «remeda a menudo las repeticiones aceleradas y entontecedoras de la cultura de consumo, el machaqueo incesante de las melodías publicitarias en televisión» ${ }^{3}$. Nunca fue la publicidad más insistente y machacona que en los años sesenta. Rosser Reeves, el gran publicitario de la agencia Ted Bates, decía que cuando un anuncio empieza a cansar al espectador es cuando comienza a ser eficaz. Las marcas se repetían en cada película publicitaria ocho o diez veces, si no más. Es fácil ver las coincidencias, los asombrosos parecidos, entre anuncios como los de Philips o Dubonnet, con su obstinación cargante en el nombre comercial, su reproducción de situaciones, su deliberado y tenaz empleo de la redundancia, con los sintagmas sonoros incesantes de Philip Glass o de Steve Reich. Cualquiera que pueda apreciar la obra de Reich Different Trains y el anuncio de Dubonnet premio en el Festival Sawa de 1965, advertirá fácilmente las coincidencias. Uno no se apoya en el otro, a mi entender, pero ambos coinciden en el uso obsesivo y ritual de la repetición. El comercial se inspiraba quizá en el viejo cartel de Cassandre de los años treinta: «Dubo. Du Bon. Dubonnet». El recurso de la repetición en publicidad es, en verdad, tan viejo como la propia publicidad. Reich se inspiraba en su propia memoria, en el ruido del tren y quizá en el jazz que ya había utilizado el sonsonete repetitivo del tren como fuente de sonido. No hay que olvidar que los minimalistas fueron una de las audiencias más fieles de los conciertos y discos de jazz.

Pero analicemos un poco más severamente estas aparentes coincidencias. Los recursos fundamentales de la música contemporánea de Cage a Michael Nyman, y en buena medida del arte desde el conceptual a hoy, parecen ser los siguientes: la

3 Ross, A. (2009): El ruido eterno, Barcelona, Seix Barral, 2010, 629. 
apropiación, la repetición y el vacío (el silencio en términos musicales). Hay otros como las dimensiones (el tamaño en escultura o la duración en música), la simplicidad extrema de las formas, sean musicales o plásticas, y la inmersión (escultura envolvente, instalaciones plásticas o sonoras, música de amueblamiento). Pero me parece que las tres primeras son las más importantes y dos de ellas (la apropiación y la repetición) son recursos básicos de la publicidad.

El discurso publicitario lleva desde el siglo XIX utilizando las efigies reconocibles de reyes, artistas y famosos de toda índole; los títulos de lugares o acontecimientos famosos (como los almacenes «Louvre» o «A la Bastille» del siglo XIX); los iconos tomados de la pintura, la escultura y el cine; fragmentos de piezas musicales bien conocidas, bandas sonoras y temas pop. Los músicos de la vanguardia de los sesenta empleaban a placer fragmentos de Beethoven o Mahler, música del Renacimiento, conciertos barrocos, jazz y rock. A eso añadieron secciones de conversaciones, ruidos callejeros: sirenas, voces, tráfico, anuncios de altavoces y otros efectos (como la botella que se rompe sobre un cajón recubierto de láminas de metal en la obra de Ligeti de 1960, Apparitions).

La publicidad, con sus repeticiones quizá idiotizantes pero sin duda eficaces en el momento, inspiró a los músicos de la vanguardia americana de los sesenta en un nuevo camino por el que todavía transitan. La repetición no es una retórica hueca, proporciona al mensaje nuevos sentidos (el del exceso, el de la exageración y el abuso), y termina produciendo en el espectador diferentes sensaciones, hastío, desagrado, alucinación, una especie de pérdida de referencias.

\section{Paisajes imaginarios}

Nuestra última instantánea nos acerca hasta los años actuales, esos años en los que el espectador está tan aburrido y tan ahíto de mensajes y de carne picada que resulta francamente difícil extraerle de su sopor mediático o de su delirio consumista. ¿Qué hacer cuando la abundancia ya no es distintiva y la repetición significa solo aburrimiento? ¿Qué se puede comprar cuando tenemos lleno el refrigerador, repleto el ropero y cansado el espíritu? Nuestros terminales están colmados de mensajes, de imágenes, de información fútil, de basura comercial, de naderías. Ha llegado el momento, pues, de la frugalidad, de la anorexia. Ya no hay que buscar la información, ahora hay que luchar contra la información porque esta es sinónimo de exceso y produce tan graves enfermedades como la obesidad. Hay una carnosidad y una pesadez del cuerpo pero también la hay de la psique saturada de mensajes, de estímulos y de demandas.

Tan solo el vacío es elegante, solo el silencio resulta distinguido, nada más que la delgadez extrema se muestra esclarecida. Lo que hay que comprar es vacío, silencio, aislamiento, ambientes en blanco, incomunicación. El lujo ya no se mide 
por la abundancia sino por el espacio, por el aire libre de polución y de ruido, por la distancia y la lentitud. Deberemos, como en la nueva música, aprender a ser lentos. Las tiendas de moda y las galerías de arte se convierten en «espacios», es decir, en lugares prácticamente vacíos, los menús de la alta cocina se resumen en viandas mínimas perdidas en grandes platos blancos, los escaparates muestran un solo objeto aislado. Basta de acumulaciones, assemblages y collages de desperdicios; basta de expositores repletos, vitrinas rebosantes y cuerpos carnosos. El momento musical es el de Morton Feldman, unas pocas notas que se distribuyen a lo largo de una enorme distancia, como un Satie ralentizado. Una música dominada por una parsimonia exasperante. Es, pues, el momento del tercer recurso: el silencio, el vacío, a cuya fuerza centrífuga nada, tampoco la publicidad, puede escapar.

Los anuncios de coches muestran a estos circulando por calles vacías (¿dónde existen esas ciudades?) o en escenarios de «lujo»: desiertos, páramos, paisajes despoblados que nos devuelvan «el placer de conducir» (Imaginary landscapes: John Cage). Las modelos escenifican con su delgadez enfermiza el rechazo de la carne, de la profusión, de la exuberancia. Los platos preparados, las cremas y los yogures huyen de la untuosidad crasa de otras épocas en beneficio de lo magro y de lo aéreo. Todo debe ser ligero, leve, transparente. Los refrescos se olvidan del azúcar, las salsas del aceite, las cremas faciales de la grasa. Todo tiende al agua, a la pureza, a la simplicidad, a la esbeltez. Por supuesto que no todos los productos se mueven en estas claves, tan sólo las grandes marcas de lujo: Chanel (Fig. 11), Gucci, Absolut, aquellas mercancías dirigidas a las gentes con necesidad de restablecer la distancia simbólica con respecto a las clases populares a estas horas ahítas de hamburguesas, ketchup, patatas fritas, refrescos, que pueblan las playas del Mediterráneo en verano, adoran las multitudes y los amontonamientos, los supermercados y las grandes superficies, utilizan colonias familiares, automóviles familiares, y se rebozan en todos sus excesos. 
Fig. 11. Chanel

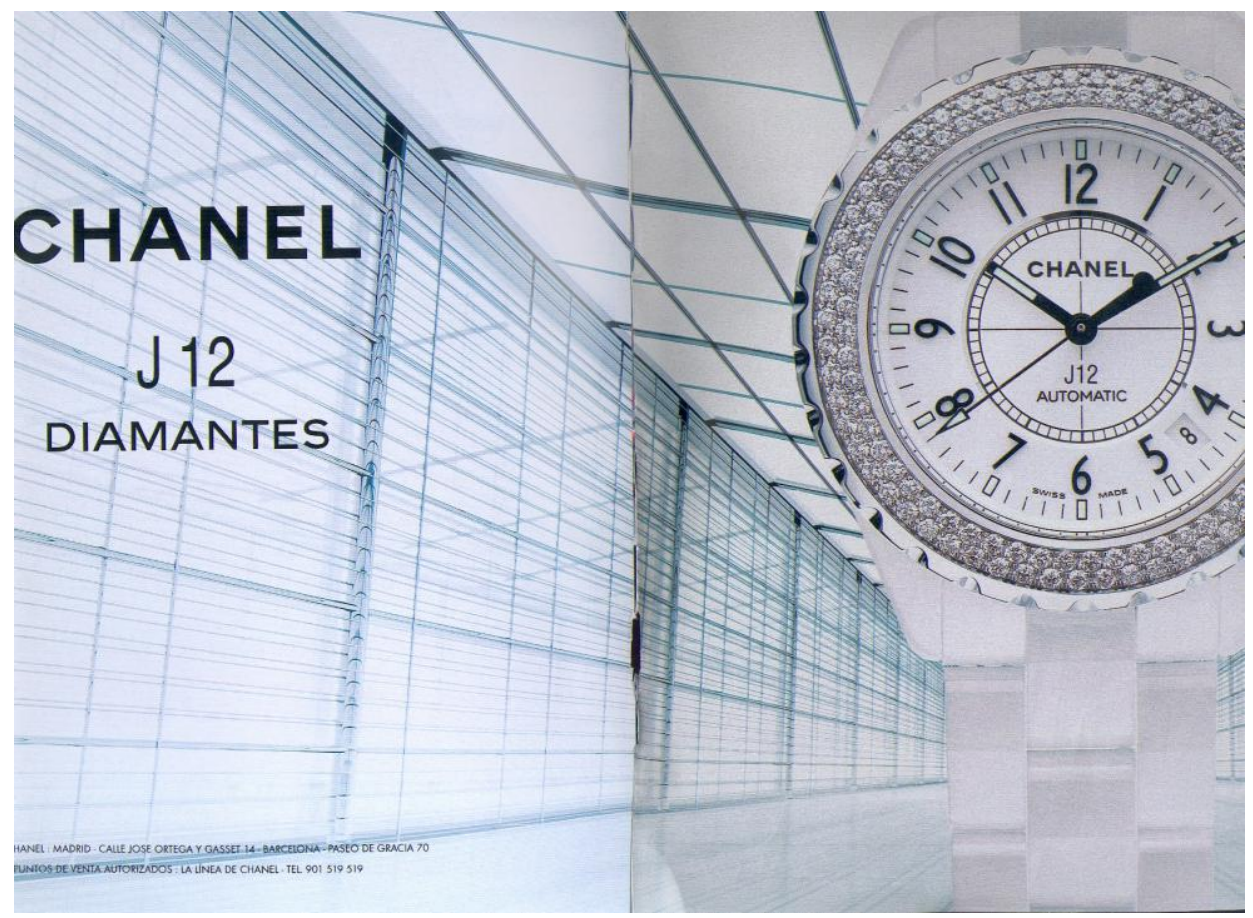

El ejemplo más representativo de este minimalismo del sigilo y la carencia, del yermo y el silencio, es sin duda el anuncio de BMW (Fig.12) que todavía resuena en nuestras cabezas: un coche no corriendo -porque la velocidad es vulgar, es de otra época, de la época del exceso y la redundancia-, sino deslizándose por una carretera desierta, la mano moviéndose levemente por la ventanilla, acariciando las crestas del aire. Un pequeño mundo, en fin, exiguo y solitario como corresponde a un momento cicatero, de un individualismo, por no decir egoísmo, profundo: « $i \mathrm{Te}$ gusta conducir?» (Puesto que lo único importante es lo que te ocurre a ti). Un mínimo de movimiento para un máximo de expresión, un mínimo de acción para conseguir un máximo de emoción, tal y como quería la música de la vanguardia mínimal. 
Fig. 12. $B M W$
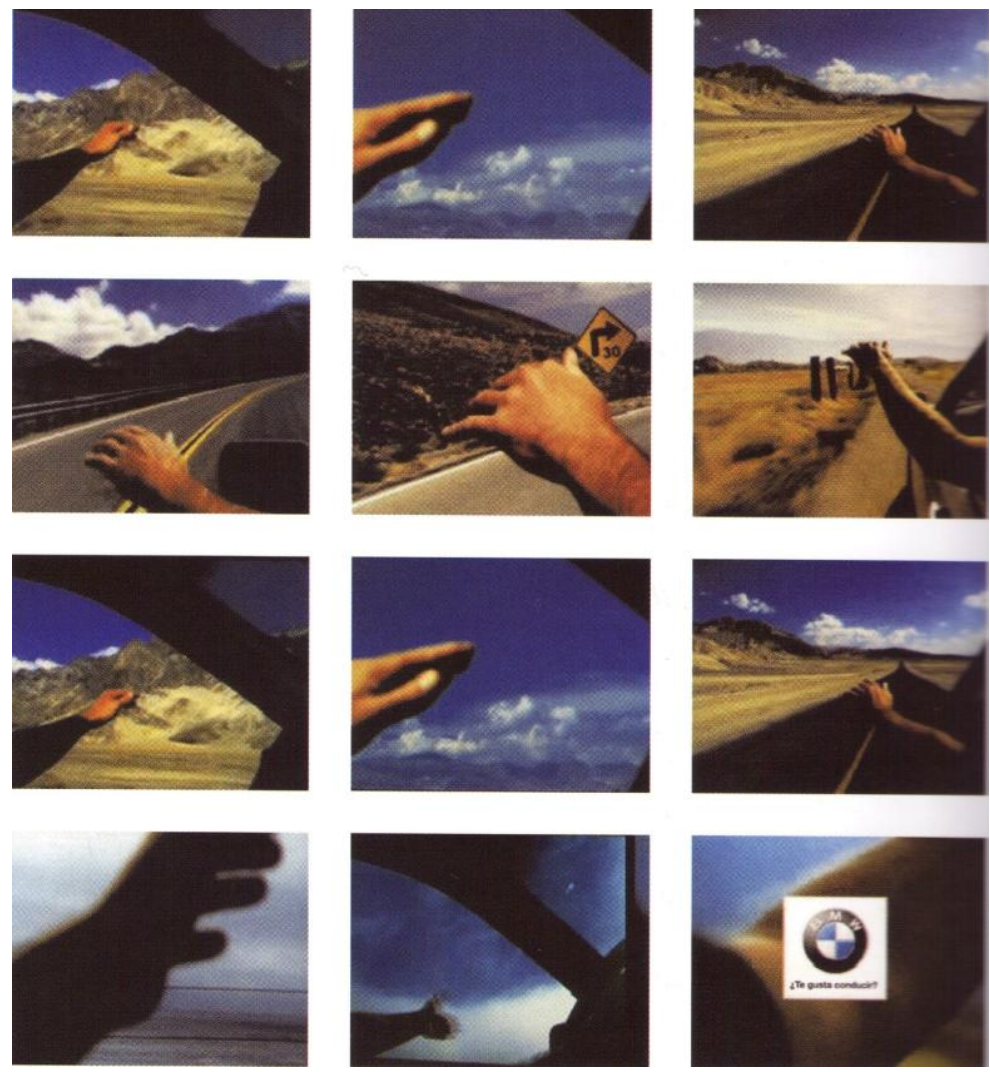

\section{Coda}

Que la publicidad constituya o no una expresión artística es, en realidad, un problema que no le interesa a nadie más que a algunos publicitarios deseosos de colocarse en un estatus diferente, más prestigioso o en apariencia más respetado socialmente. El hecho es que los vínculos entre el arte y la publicidad existen desde el inicio de esta, y así mismo desde el nacimiento del concepto moderno del arte. Ambos, arte moderno y publicidad, son consecuencia, en definitiva, del proceso de modernización de nuestras sociedades.

En la medida en que lo que define el arte actual es el continente, el escenario, y pensando en que todos los grandes museos de arte han dado cabida entre sus paredes a piezas publicitarias, la discusión se ha terminado: la publicidad es arte, o quizá mejor: ciertas piezas publicitarias son arte, porque las autoridades artísticas lo han decidido así, al menos mientras se mantengan dentro del recipiente que 
define lo artístico. La publicidad tiene sus soportes: «esto es publicidad en la medida en que ocupa los espacios o tiempos publicitarios»; y así mismo ocurre con el arte; todo lo que aparezca recogido en los escenarios del arte entra a formar parte de dicha categoría.

$\mathrm{Y}$, no obstante, nunca ha sido menos influyente la publicidad sobre la escena artística que hoy mismo. Escrutando las fechas y los vínculos formales artepublicidad queda de manifiesto que ese ascendente fue muy marcado desde finales del siglo XIX, y se fue perdiendo con el tiempo. Hacia 1950 se producen interferencias entre ambos espacios de manera más o menos simultánea. Mientras que en nuestro tiempo es notablemente la publicidad la que busca su inspiración en el arte contemporáneo, no siempre con demasiado acierto. Lo cierto es que según ha ido asumiendo la clase publicitaria una conciencia artística, ha ido perdiendo su fuerza original, su valor y su influencia sobre el escenario del arte. Los publicitarios del siglo XIX e inicios del XX carecían de cualquier intención artística, desconocían que su trabajo tuviese nada que ver con el arte, y si desarrollaron una retórica y una estética fue con el objetivo de solventar las dificultades de su oficio y ser más eficaces; y sin embargo ese fue el momento en que resultó mayor su ascendente sobre el contexto artístico.

\section{Referencias bibliográficas}

Benjamin, W. (1955): Dirección única, Madrid, Alfaguara, 1987. Ross, A. (2009): El ruido eterno, Barcelona, Seix Barral, 2010 